\title{
Lautropia mirabilis gen. nov., sp. nov., a Gram- negative motile coccus with unusual morphology isolated from the human mouth
}

\author{
P. Gerner-Smidt, ${ }^{1}$ H. Keiser-Nielsen, ${ }^{3}$ M. Dorsch, ${ }^{4}$ E. Stackebrandt, ${ }^{5}$ \\ J. Ursing, ${ }^{6}$ J. Blom, ${ }^{2}$ A. C. Christensen, ${ }^{7}$ J. J. Christensen, ${ }^{1}$ W. Frederiksen, ${ }^{1}$ \\ S. Hoffmann, ${ }^{1}$ W. Holten-Andersen ${ }^{1}$ and Y. T. Ying ${ }^{8}$
}

Author for correspondence: P. Gerner-Smidt. Tel: +45326832 68. Fax: +4532683868.

\footnotetext{
1, 2 Departments of Clinical Microbiology ${ }^{1}$ and Molecular Cell Biology, 2

Statens Seruminstitut, Artillerivej 5, DK-2300 Copenhagen S, Denmark

3 Haraldsborgvej 7, DK-4000 Roskilde, Denmark

4 Centre for Bacterial Diversity and Identification, Department of Microbiology, The University of Queensland, St Lucia, QId 4072, Australia

5 Deutsche Sammlung für Mikroorganismen und Zellkulturen $\mathrm{GmbH}$, Maschleroder Weg 1B, D3300 Braunschweig, Germany

6 Department of Medical Microbiology, Lund University, Malmö General Hospital, S-214 01 Malmö, Sweden

7 Carrea del Rost 2 A, 08328 Alella, Spain

8 III Building 2, Unit 208, XibaHei Dong Li, Chao Yang Districts, (100028) Beijing, China
}

\begin{abstract}
An organism that seems to be identical to Ørskov's ' Sarcina mirabilis' [Ørskov, J. (1930) Acta Pathol Microbiol Scand Suppl III, 519-541] has been rediscovered in specimens from the upper respiratory tract of humans. Six strains were studied, and the results, which conformed to Ørskov's description of $S$. mirabilis, were as follows. Rough to smooth colonies grow on many plated media and show extremely polymorphic cell morphology with round cells with diameters from 1 to $>10 \mu \mathrm{m}$. The smallest cells were often motile with circular movements. Strains were Gram-negative, facultatively anaerobic, oxidase and urease positive, and weakly catalase positive. Nitrate and nitrite were reduced, and glucose, fructose, sucrose and mannitol were fermented. Polysaccharide was produced on sucrose agar. Electron microscopy showed coccoid cells with a bundle of three to nine flagella, a Gram-negative cell-wall morphology, and aggregates of irregular cells held together by a common surface layer. The mean mol\% $(G+C)$ of the organisms was 65.0. 165-ribosomal RNA sequencing revealed that the organism belongs to the beta subgroup of Proteobacteria, separate from all other described genera, but most closely related to Burkholderia. The name Lautropia mirabilis is proposed for this organism.
\end{abstract}

\footnotetext{
Keywords: Lautropia mirabilis gen. nov., sp. nov., motile Gram-negative cocci,
} ultrastructure, phylogenetic position

\section{INTRODUCTION}

The present investigation was prompted by an observation by one of us (H.K.-N.) on studying microscopically human saliva sampled from the back of the tongue. Frequently, coccal organisms with very rapid circular movements were seen. Although many motile organisms exist in the human mouth, on the teeth, and in the pharynx, the observed coccal organism did not seem to belong to any of the well known groups. Accordingly,

Abbreviations: PGUA, $\beta$-glucuronidase; PNPX, $\beta$-xylosidase; VP, VogesProskauer. the literature was searched for reports of similar organisms, and an attempt was made to isolate and characterize these unusual bacteria.

We owe to the late Dr Hans Lautrop the reference to a paper by J. Orskov from 1930, describing a peculiar organism which he isolated on Bordet-Gengou coughplates from patients suspected of pertussis and described as 'Sarcina mirabilis' (Orskov, 1930).

Unfortunately, no strains of Ørskov's bacteria had been kept at the Statens Seruminstitut, Copenhagen, Denmark. Thus a search was made using Bordet-Gengou plates without antibiotics (H.K.-N. \& W.F.) for organisms 
fitting Ørskov's description. We succeeded in finding colonies that contained organisms fitting Ørskov's description, which turned out to be rather common, as also found by Ørskov. Schiött (1967) isolated strains, with similar characteristics, from the gingival margin of persons experimentally rinsing their mouths with a solution of $0.5 \%$ vancomycin. One of these strains had been studied in the Department of Clinical Microbiology at the Statens Seruminstitut (H. Lautrop, unpublished observation) and was kept. Klesius et al. (1962) described a similar organism isolated from human saliva. However, there appears to be no systematic description of this unusual organism apart from Ørskov's in 1930. When a similar clinical isolate was recently sent to our department for identification from a local Danish clinical microbiological laboratory, we made a thorough examination of all strains kept. The present paper presents the results of this investigation.

\section{METHODS}

Strains. Six strains were studied: two were originally isolated from the gingival margin of healthy persons in the 1960s (strain nos AB2188 and AB2512; Schiött, 1967), three were isolated in 1983 from cough-plates (Bordet-Gengou plates without penicillin) from patients with suspected whooping cough (strain nos $\mathrm{AB} 2189, \mathrm{AB} 2190$ and $\mathrm{AB} 2191$ ); a recent isolate from a drain in the frontal sinus of a patient recovering from a streptococcal sinusitis (strain no. AB2450). All strains were thought to be saprophytes. The first five strains had been kept freeze-dried until this study; the last isolate was kept in broth supplemented with $10 \%(\mathrm{v} / \mathrm{v})$ glycerol at $-70^{\circ} \mathrm{C}$.

Micromorphology. Strains were observed with a phase contrast microscope in wet mounts from all media which supported growth of the organisms. In addition the strains were Gram-, methylene-blue- and Ziehl-Neelsen-stained (Hendrichson \& Krenz, 1991) and observed with a bright-field light microscope.

Electron microscopy. Negative staining was performed, with $1 \%(\mathrm{w} / \mathrm{v})$ ammonium molybdate, $\mathrm{pH} 7 \cdot 4$, on young cultures (24-48 h) grown on chocolate agar, as previously described (method A in Blom et al., 1983). For thin sectioning, small isolated colonies were punched out from the plates with a hypodermic needle (1 $\mathrm{mm}$ in diameter) and fixed in $3 \%(\mathrm{v} / \mathrm{v})$ glutaraldehyde in $0.1 \mathrm{M}$ cacodylate buffer, $\mathrm{pH} 7 \cdot 2$, containing $0.01 \mathrm{M} \mathrm{CaCl}_{2}$ overnight at $4{ }^{\circ} \mathrm{C}$. Post-fixation was carried out for $90 \mathrm{~min}$ in $1 \%(\mathrm{w} / \mathrm{v}) \mathrm{OsO}_{4}$ in $0.1 \mathrm{M}$ cacodylate buffer, $\mathrm{pH} \mathrm{7.2,}$ containing $0.01 \mathrm{M} \mathrm{CaCl}$, followed by $1 \mathrm{~h}$ treatment in $2 \%$ (w/v) uranyl acetate in barbiturate buffer, $\mathrm{pH} 7 \cdot 3$. After dehydration and embedding in Vestopal (Martin Jaeger, Geneva), sectioning and further preparation for electron microscopy followed the method of Melchior et al. (1973).

Growth characteristics. Growth was tested on 15 solid media manufactured at the Statens Seruminstitut: $5 \%(\mathrm{v} / \mathrm{v})$ and $10 \%$ (v/v) horse-blood agar, chocolate agar, CAMP plates (bilayered plates containing beef infusion agar in the bottom and $5 \%$ sheep-blood agar in the top layer), modified Drigalski plates containing $0.9 \%$ lactose and $0.01 \%$ bromothymol blue, MacConkey agar, beef infusion agar with $0.03 \%$ sodium azide and $5 \%$ defibrinated horse blood, beef extract agar, beef infusion agar containing $0.04 \%$ tellurite and $10 \%$ defibrinated horse blood, egg yolk agar (EYA), Tween 80 agar, $40 \%$ (v/v) bile agar with $8 \%$ defibrinated horse blood, beef infusion agar without supplements, Levinthal agar containing glucose, yeast extract and NAD, and tryptose glucose yeast extract (TGY) agar plates. Material from a single colony of each strain grown overnight on chocolate agar was spread on each plate, incubated aerobically and inspected daily for $8 \mathrm{~d}$. If no growth occurred after $8 \mathrm{~d}$, the procedure was repeated using material from several colonies taken with a $10 \mu \mathrm{l}$ inoculating loop. Testing for anaerobic growth was performed in an anaerobic incubator (Forma Scientific) on TGY plates and $5 \%$ blood agar. A strain of Acinetobacter calcoaceticus served as a negative control. The strains were tested for growth at $22^{\circ} \mathrm{C}, 30^{\circ} \mathrm{C}, 35^{\circ} \mathrm{C}, 41^{\circ} \mathrm{C}$, $44^{\circ} \mathrm{C}$ and $48^{\circ} \mathrm{C}$ by inoculation from a chocolate agar plate culture to semi-solid agar $(0.3 \%$ agar $)$ in a waterbath. Similarly, the strains were tested for growth at $22^{\circ} \mathrm{C}, 35^{\circ} \mathrm{C}, 41^{\circ} \mathrm{C}$ and $44^{\circ} \mathrm{C}$ in beef infusion broth. All cultures were observed for $7 \mathrm{~d}$. The strains were tested for salt tolerance in beef infusion broth with $2.5 \%$ (w/v) $\mathrm{NaCl}$ at $35^{\circ} \mathrm{C}$ for $7 \mathrm{~d}$. Broth cultures without $\mathrm{NaCl}$ served as controls.

Biochemical tests. Oxidase production was determined by the method of Kovács (1956) with $1 \%$ tetramethyl-p-phenylenediamine dihydrochloride, using a 48 -h-old beef infusion agar culture; a dark-purple colour within $10 \mathrm{sec}$ was considered a positive reaction. Catalase production was detected by harvesting a 48-h-old beef infusion agar culture and adding it to a drop of $10 \%(v / v) \mathrm{H}_{2} \mathrm{O}_{2}$ on a slide. To test for nitrate reduction, sulfanilic acid and 1-naphthylamine-7-sulfonic acid were added to 2- and 4-d-old cultures of beef infusion broth containing $0.02 \% \mathrm{KNO}_{3}$; zinc powder was added when no colour reaction took place. The test for the ability to reduce nitrite was also done with the same reagents in beef infusion broth containing $0.02 \% \mathrm{NaNO}_{2}$. For determination of acetoin production (Voges-Proskauer test), the method of O'Meara (1931) was used, with incubation for $4 \mathrm{~d}$. Gelatin liquefaction was tested at $22{ }^{\circ} \mathrm{C}$ using the classical gelatin stab (Koch, 1884) with observation for up to $10 \mathrm{~d}$. A culture in TSI medium without carbohydrates (Kolmos \& Schmidt, 1987) was observed over $10 \mathrm{~d}$ to detect $\mathrm{H}_{2} \mathrm{~S}$ production. $\beta$-Galactosidase production was detected by the method of Bülow (1964) with $0.2 \%$ ONPG. Tests for production of $\beta$-glucuronidase (PGUA) and $\beta$ xylosidase (PNPX) were done according to Kilian \& Bülow (1976). For detection of urease production, a heavy suspension was made in a potassium phosphate buffer containing $1 \%(\mathrm{w} / \mathrm{v})$ urea and phenol red as indicator; a solution without urea was used as control (Lautrop, 1960). Phenylalanine deaminase production was detected by making a heavy suspension from a chocolate agar culture in phenylalanine $(0.5 \%)$ in distilled water and adding a few drops of an $\mathrm{FeCl}_{3}$ solution after incubation for $24 \mathrm{~h}$ (modified from Bergquist \& Searcy, 1963). For detection of decarboxylase/dihydrolase production, Møller's arginine, lysine and ornithine media were used and observed for $10 \mathrm{~d}$ (Møller, 1955). Esculin hydrolysis was tested as described by Vaughn \& Levine (1942). Hippurate hydrolysis was tested for using the method of Carlsson (1968). Polysaccharide production was tested on sucrose agar plates as described by Neubauer \& Berger (1961). Tests for production of levan and dextran were done by precipitation with ethanol (Gibbons \& Banghart, 1967). Production of acid from carbohydrates was tested in open oxidation/fermentation tubes (Hugh \& Leifson, 1953) observed for up to $14 \mathrm{~d}$.

Susceptibility testing. The strains were tested for susceptibility to penicillin, ampicillin, piperacillin, cefuroxime, erythromycin and gentamicin using the tablet diffusion method with Rosco NeoSensitabs (Rosco, Tåstrup, Denmark) on Danish Blood agar. 


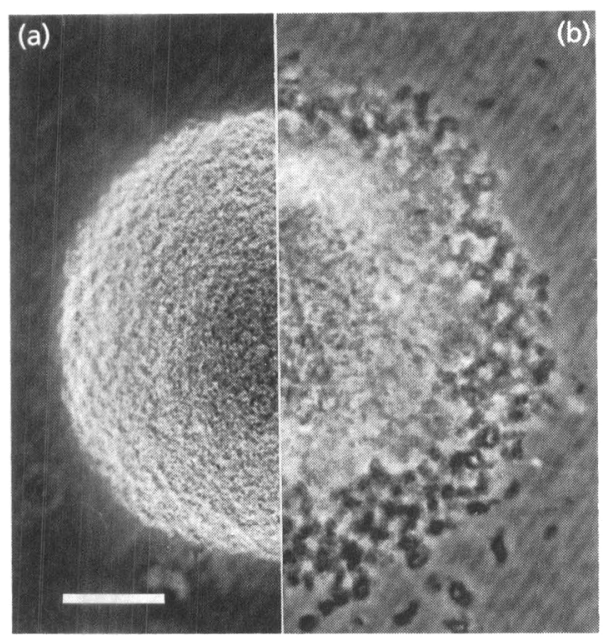

Fig. 1

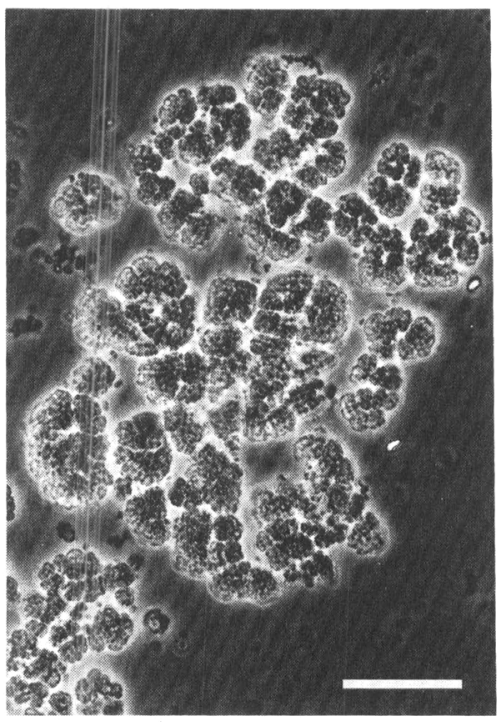

Fig. 2

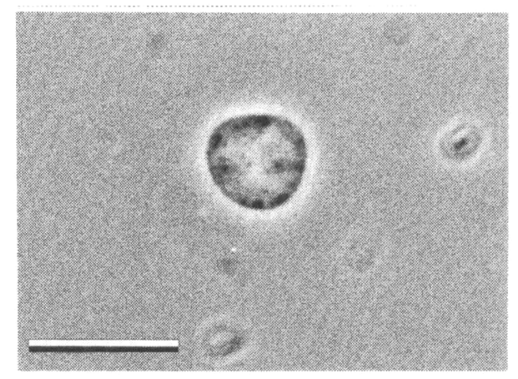

Fig. 3

Fig. 1. (a) Round colony from 24 -h-old culture on Levinthal agar under phase contrast. Bar, $20 \mu \mathrm{m}$. (b) As (a) but with motile forms in the periphery of the colony.

Fig. 2. Cluster of round cells from 2-d-old broth culture under phase contrast. Bar, $10 \mu \mathrm{m}$.

Fig. 3. Sphaeroblast-like form in 2-d-old broth culture under phase contrast. Bar, $10 \mu \mathrm{m}$.

Plasmid isolation. Isolation of plasmids was attempted using the method of Gerner-Smidt (1989), which is a modification of the boiling method of Holmes \& Quigley (1981). However, the cells were disrupted only after treatment with both lysozyme $(4 \%, w / v)$ and lysostaphin $(0 \cdot 1 \%)$.

Determination of $\mathbf{m o l} \%(\mathbf{G}+\mathbf{C})$. The protocol for isolation of DNA has been given by Lind \& Ursing (1986). Mol\% $(\mathrm{G}+\mathrm{C})$ was estimated by thermal denaturation, following the procedure described by Sandstedt et al. (1983).

165 rRNA sequencing. Amplification of the $16 \mathrm{~S}$ rRNA gene and purification of the PCR products of strains AB2188 and AB2450 were performed as described previously (Rainey et al., 1992; Rainey \& Stackebrandt, 1993). The double-stranded PCR products were sequenced (Dorsch \& Stackebrandt, 1992) using primers described previously (Stackebrandt \& Charfreitag, 1990).

Analysis of the sequence data. The sequence of strain AB2188, which has been deposited in EMBL under accession number $\mathrm{X} 73223$, was aligned to the database of small subunit rRNAs (Olsen et al., 1992). After an initial analysis showed the sequence to be related to those of members of the beta-subclass of Proteobacteria, subsequent analyses were restricted to sequences available for organisms of this subclass. The final analysis was performed with organisms shown in Table 3 and Fig. 7. Sequence regions that either were not determined in one or more of the reference organisms or were of alignment uncertainty, i.e. positions $5^{\prime}$ terminus through 107, and 1376 through the $3^{\prime}$ terminus (Escherichia coli nomenclature; Brosius et al., 1978) had to be omitted. About 1270 nucleotides were used in the phylogenetic analysis. Pairwise evolutionary distances (expressed as estimated changes per 100 nucleotides) were computed from percentage similarities by the correction of Jukes \& Cantor (1969). A phylogenetic tree was constructed from the distance matrix by the algorithm of De Soete (1983). Sequence alignment and data comparison were done using a SUN SPARC IPC Workstation.

\section{RESULTS}

\section{Micromorphology}

On solid media the colonies were very pleomorphic. At least three different colony types were found. In young cultures, flat, dry, circular colonies predominated, most of these colonies becoming larger, wrinkled, crisp and crateriform on prolonged incubation; this latter colony type predominated in cultures older than $1 \mathrm{~d}$. The third colony type was smooth, glistering, raised, round and rather mucoid. All colony types were usually adherent to the substrate. However, from some substrates, especially Levinthal agar, colonies could easily be removed in toto. All colony types in every size were found on all plated media supporting growth. The colony size varied between pin-point size up to more than $5 \mathrm{~mm}$ in diameter, a size which was reached in 4-7 d on enriched media incubated at $35^{\circ} \mathrm{C}$. Subculture from any colony form resulted in growth of all colony types. All colonies were nonpigmented. In fluid media, such as beef infusion broth, growth was granular with a coarse sediment at the bottom and adherent granules on the side of the tube. These adherent granules were easily loosened by agitation. When viewing the plate cultures under phase-contrast, it was 


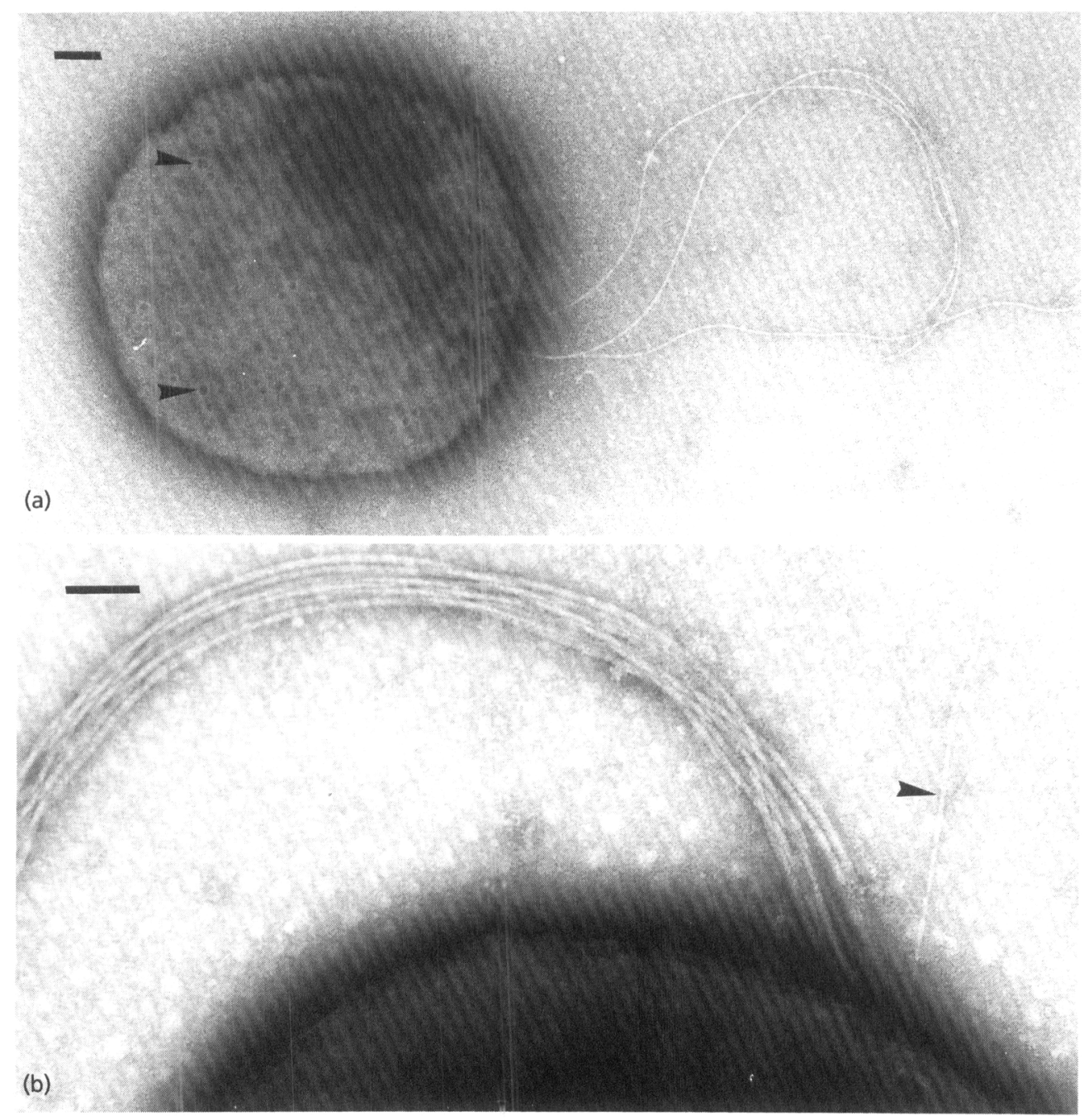

Fig. 4. Electron micrographs of negatively stained cells grown on chocolate agar. (a) Cell with a flagellar tuft and regular round structures localized on the cell surface (arrowheads) (X32000; bar, $0.2 \mu \mathrm{m})$. (b) Higher magnification of a flagellar tuft containing nine flagella and a single fimbria (arrowhead) $(X 90000 ;$ bar, $0.1 \mu \mathrm{m})$.

seen that growth started in clumps of cells held together in an amorphous matrix (Fig. 1a). After a few hours incubation at $35^{\circ} \mathrm{C}$ motile cocci appeared at the periphery of the colony (Fig. 1b). In one preparation at least three cell types were seen; capsulated cocci, 1-2 $\mu \mathrm{m}$ in diameter, motile cocci of similar size, and large sphaeroblast-like cells. In wet mounts the capsulated cells were seen floating freely or in clumps resembling sporangia with less than 10 to more than 100 cells in each cluster (Fig. 2). In cells of the second type, the motion was seen starting as a quivering developing into a fast movement in ever increasing circles. The last type was a large, $5->10 \mu \mathrm{m}$ in diameter, sphaeroblast-like form (Fig. 3). The capsulated form predominated in cultures of all ages, the motile forms were mostly seen in cultures a few days old, and the sphaeroblast-like forms in older cultures. All forms were Gram-negative, not acid-fast and easily stained with $1 \%$ $(\mathrm{w} / \mathrm{v})$ methylene blue. The micromorphology in methyl- ene-blue-stained broth cultures showed predominantly sporangia-like structures containing numerous round cells.

\section{Electron microscopy}

In negatively stained preparations the motile cells were globular or coccoid $(1 \cdot 5-2 \cdot 0 \mu \mathrm{m}$ in diameter) with a tuft of flagella arising from one point of the cell wall (Fig. 4). The number of flagella varied from three to nine. On some cells single fimbriae were also seen (Fig. 4b). Another observation disclosed by negative staining was a number of regular round structures with a diameter of about $30 \mathrm{~nm}$ randomly localized on the cell surface (Fig. 4). In the thin-sectioning preparations the ultrastructure of the microcolonies fixed in situ showed two cell forms: (i) a coccoid cell localized at the outermost part of the microcolonies (Fig. 5a) and (ii) aggregates of irregular 


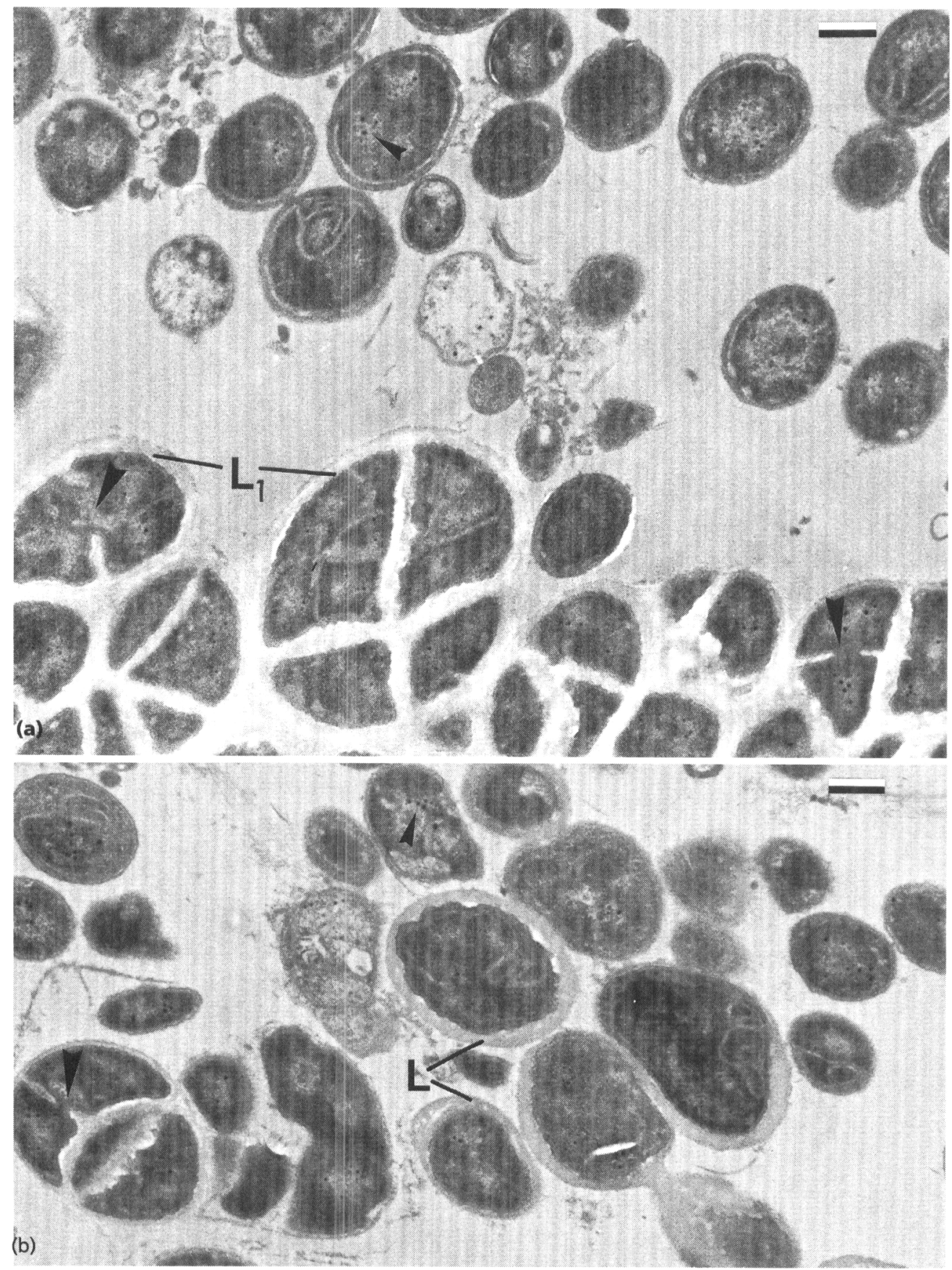

Fig. 5. Survey electron micrographs of thin sectioning from the border of a microcolony (X15000; bar, $0.5 \mu \mathrm{m})$. Free coccoid cells with $(L)$ and without a surface layer are found together with irregular cells embedded in a similar layer $\left(L_{1}\right)$. Binary fissions (big arrowheads) are seen in some cells. Small electron-dense granules (small arrowheads) are found in many of the cells.

cells held together by a common surface layer (Fig. 5). Between the irregular cells a cementing layer of varying thickness was seen (Figs 5 and $6 c$ ). After the rupture of the common surface layer, some cells continued to have a thick surface layer (Figs $5 \mathrm{~b}$ and $6 \mathrm{~b}$ ). The coccoid cells varied in diameter from 0.7 to $2.0 \mu \mathrm{m}$, whereas some irregular cells showed a conglomerate appearance more than $3 \mu \mathrm{m}$ in diameter (Fig. 5b). Both cell forms showed a typical Gram-negative cell-wall profile, i.e. two triplelayer membranes with a thin peptidoglycan layer in between (Fig. 6a, c). In contrast to ordinary Gramnegative cells many of these bacteria showed membranous structures, which were found parallel to the plasma membrane (Fig. 6a) or seen as vacuoles (Fig. 6c). The cementing layer found between the cells in the aggregates was of medium electron density (Fig. 6c) and morpho- 

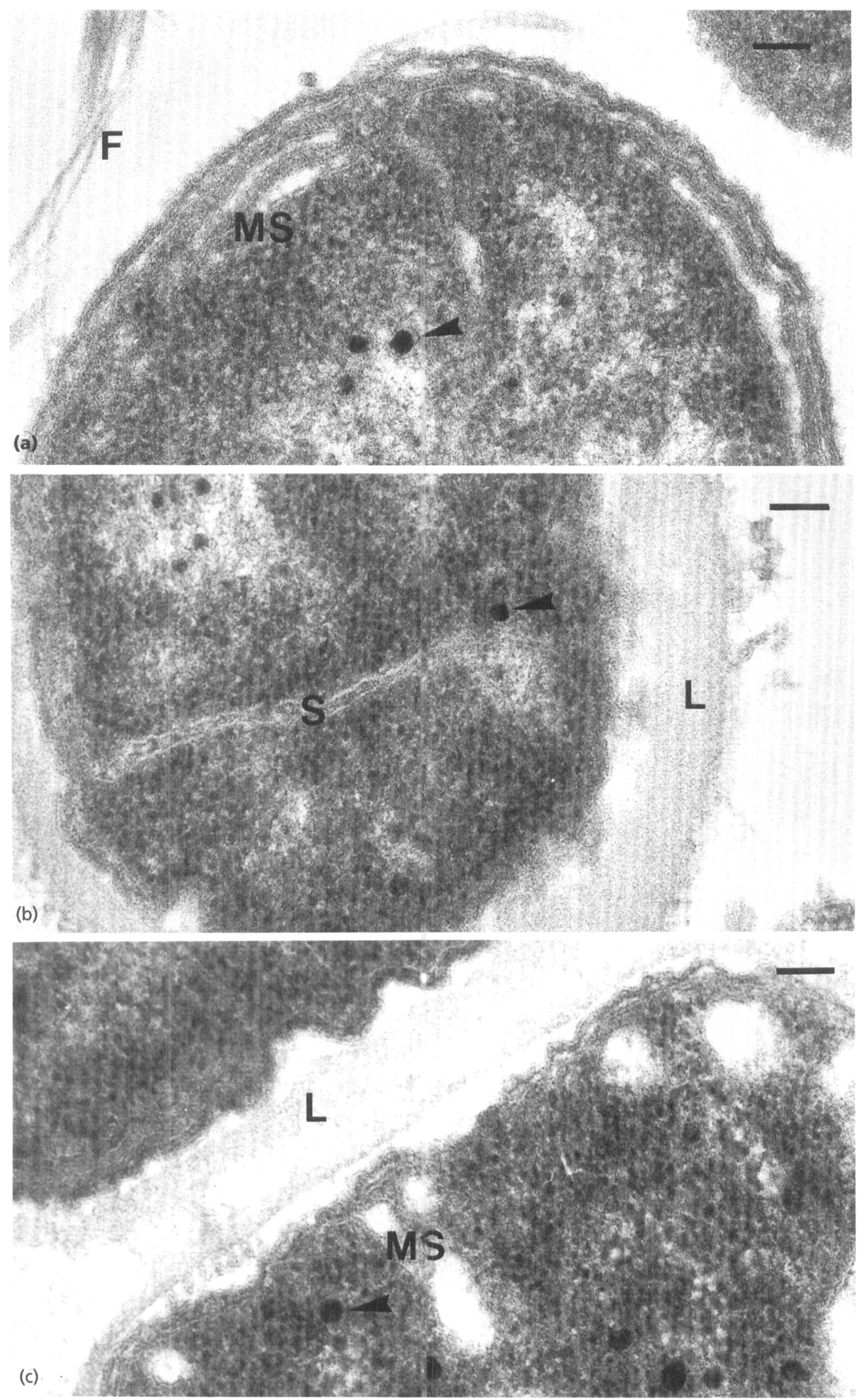

Fig. 6. Representative details from cells prepared for thin sectioning (X90000; bar, $0.1 \mu \mathrm{m})$. (a) Part of a cell without any surface layer. Membranous structures (MS), electron-dense granules (arrowhead) and a bundle of flagella (F) are seen. (b) Part of a cell with a thick surface layer (L) and a dividing septum (S). Electron-dense granules (arrowhead) are seen. (c) Part of a cell aggregate with thick cementing layer (L) between the cells, small membranous structures (MS) and electrondense granules (arrowhead). 
Table 1. Growth on plated media at $35^{\circ} \mathrm{C}$ without $\mathrm{CO}_{2}$

Results are the number of strains out of six showing growth after 1 or $2 \mathrm{~d}$ or no growth by day 7 .

\begin{tabular}{|c|c|c|c|}
\hline \multirow[t]{2}{*}{ Substrate } & \multicolumn{2}{|c|}{$\begin{array}{c}\text { Day visible } \\
\text { growth } \\
\text { observed }\end{array}$} & \multirow{2}{*}{$\begin{array}{c}\text { No } \\
\text { growth } \\
\text { by day } \\
7\end{array}$} \\
\hline & 1 & 2 & \\
\hline 5 and $10 \%(w / v)$ horse blood agar* & $2 / 6$ & $6 / 6$ & \\
\hline CAMP plate (5\% sheep blood)* & $2 / 6$ & $6 / 6$ & \\
\hline Chocolate agar & $6 / 6$ & & \\
\hline TGY'agart & $6 / 6$ & & \\
\hline Levinthal agar & $6 / 6$ & & \\
\hline Tween 80 & $6 / 6$ & & \\
\hline Beef infusion agar & $1 / 6$ & $6 / 6$ & \\
\hline Beef extract agar & $2 / 6$ & $6 / 6$ & \\
\hline Tellurite agar & $1 / 6 \dagger$ & & $5 / 6$ \\
\hline 'Enteric' media $\ddagger \rrbracket$ & & & $6 / 6$ \\
\hline Sodium azide agar $\ddagger$ & & & $6 / 6$ \\
\hline EYA agar $\ddagger$ & & & $6 / 6$ \\
\hline $40 \%$ bile agar $\ddagger$ & & & $6 / 6$ \\
\hline
\end{tabular}

* No haemolysis.

$\dagger$ Weak growth, no discoloration.

$\ddagger$ W'eak growth on all media using excessive inoculum.

¿'Fnteric' media are MacConkey agar and modified Drigalski plates.

logically similar to the thick surface layer found in some of the free cells (Figs $5 \mathrm{~b}$ and $6 \mathrm{~b}$ ). Multiplication of the cells appeared to be only by binary fission and was only seen in the aggregates. Sections of cells in the process of crosswall formation are found in Fig. 5. Another characteristic feature was the appearance of small electron-dense granules observed in both the coccoid and irregular cells (Fig. 5). These were localized to the nuclear regions of the cells and seen at higher magnification their diameters were found to be $30-40 \mathrm{~nm}$ (Fig. 6).

\section{Growth characteristics}

Table 1 lists the plated media that supported growth of the strains. They all grew on all non-selective media except EYA agar. Growth was best on chocolate agar, TGY agar and Levinthal agar. One strain (strain AB2188) grew weakly on tellurite agar after $2 \mathrm{~d}$ incubation with no discoloration of the medium or pigmentation of the colonies. No growth was seen on the modified Drigalski, MacConkey agar, sodium azide agar, EYA, or bile agar plates using the small inoculum. Even with an excessive inoculum only slight growth was seen on these media. None of the strains were able to grow at $22{ }^{\circ} \mathrm{C}$ or $48{ }^{\circ} \mathrm{C}$.
All strains grew at $30^{\circ} \mathrm{C}, 35^{\circ} \mathrm{C}, 41^{\circ} \mathrm{C}$ and $44^{\circ} \mathrm{C}$; however, growth was slower at the latter temperature. All strains grew slowly under anaerobic conditions, without haemolysis. No strain grew in broth with $2.5 \%(\mathrm{w} / \mathrm{v})$ $\mathrm{NaCl}$.

\section{Biochemical tests}

The biochemical characteristics of the strains were very uniform as shown in Table 2. All strains were positive in tests for oxidase, catalase, urease, nitrate and nitrite reduction, and polysaccharide production on sucrose agar. All strains fermented glucose, fructose, maltose and sucrose in 1-2 d. All strains except strain AB2190 fermented mannitol within $4 \mathrm{~d}$, the latter strain did so only weakly after $14 \mathrm{~d}$; two strains (AB2191 and AB2512) were able to produce acid from galactose within 1-3 d. Four strains (AB2189, AB2190, AB2191 and AB2512) produced $\beta$-xylosidase (the tests were positive within $2 \mathrm{~h}$ ); all strains, except AB2188, were able to hydrolyse esculin within 1-4 d. All strains showed negative ONPG and PGUA reactions; tests for phenylalanine deaminase, amino-acid decarboxylases, VP, gelatinase, dextran, levan, $\mathrm{H}_{2} \mathrm{~S}$ production, hippurate hydrolysis, and fermentation of lactose, trehalose, raffinose, inulin, salicin, adonitol, dulcitol, sorbitol, inositol, xylose, rhamnose, arabinose and starch were also negative.

\section{Antibiotic susceptibility}

All strains were sensitive to penicillin, ampicillin, erythromycin, piperacillin, cefuroxime and gentamicin.

\section{Plasmids}

No plasmids were found in any strain.

\section{Mol \% (G+C)}

The mol \% $(\mathrm{G}+\mathrm{C})$ for five strains ranged from 64.6 to 65.4 with a mean of 65.0 . The value for strain AB2188 was $65 \cdot 3$.

\section{Phylogenetic analysis}

A stretch of 1440 nucleotides of the $16 \mathrm{~S}$ rDNA sequence of the motile coccus strains AB2188 and AB2450 were analysed, covering region 44 through to 1495 of the E. coli sequence. The sequences of strains AB2188 and AB2450 were identical when the few positions of sequence ambiguity of the latter strain were omitted from the pairwise comparison. Because of sequence identity only strain AB2188 was included in the phylogenetic analysis. The results indicate that the motile coccus is a member of the beta-subclass of Proteobacteria, showing no close relationship to any of the taxa that belong in this subclass. The highest similarity values are those with Burkbolderia cepacia (92.3\% similarity) (Table 3 ) and other members of this genus, which includes the human pathogenic species B. mallei and B. pickettii (Li et al., 1993). The graphic representation of dissimilarity values (Fig. 7) 
Table 2. Biochemical tests positive or negative for all strains

\begin{tabular}{|c|c|}
\hline Positive & Negative \\
\hline $\begin{array}{l}\text { Oxidase production } \\
\text { Catalase production (weak) } \\
\text { Urease production (15 min) } \\
\text { Nitrate reduction } \\
\text { Nitrite reduction } \\
\text { Polysaccharide production } \\
\text { Acid from: } \\
\qquad \text { Glucose }(1-2)^{*} \\
\text { Fructose }(1)^{*} \\
\text { Maltose }(1)^{*} \\
\text { Sucrose }(1)^{*} \\
\text { Mannitol }(3-4)^{*} \dagger\end{array}$ & $\begin{array}{l}\text { ONPG ( } \beta \text {-galactosidase) } \\
\text { PGUA ( } \beta \text {-glucuronidase) } \\
\text { Phenylalanine deaminase } \\
\text { Arginine decarboxylase/dihydrolase } \\
\text { Lysine decarboxylase } \\
\text { Ornithine decarboxylase } \\
\text { VP } \\
\text { Gelatinase } \\
\mathrm{H}_{2} \mathrm{~S} \text { production } \\
\text { Hippurate hydrolysis } \\
\text { Tween } 80 \text { hydrolysis } \\
\text { Dextran }\} \text { production from sucrose } \\
\text { Levan }\} \text { Acid from: lactose, trehalose, raffinose, } \\
\text { inulin, salicin, adonitol, dulcitol, } \\
\text { sorbitol, inositol, xylose, rhamnose, } \\
\text { arabinose, starch }\end{array}$ \\
\hline
\end{tabular}

* Number in parentheses indicates day of positive reaction.

† Strain AB2190 was an exception, which showed only a weak positive reaction after $14 \mathrm{~d}$ observation.

Table 3. 16S rDNA sequence similarity values

\begin{tabular}{|c|c|c|c|c|c|c|c|c|c|c|c|c|c|c|c|c|c|c|c|c|}
\hline & 1 & 2 & 3 & 4 & 5 & 6 & 7 & 8 & 9 & 10 & 11 & 12 & 13 & 14 & 15 & 16 & 17 & 18 & 19 & 20 \\
\hline Motile coccus AB2188 & - & & & & & & & & & & & & & & & & & & & \\
\hline 2. Alcaligenes eutrophus & $90 \cdot 6$ & - & & & & & & & & & & & & & & & & & & \\
\hline 3. Alcaligenes faecalis & $90 \cdot 7$ & $89 \cdot 0$ & - & & & & & & & & & & & & & & & & & \\
\hline 4. Comamonas testosteroni & $89 \cdot 1$ & $89 \cdot 4$ & 87.6 & - & & & & & & & & & & & & & & & & \\
\hline Cbromobacterium violaceum & $89 \cdot 9$ & $90 \cdot 0$ & $88 \cdot 5$ & $86 \cdot 4$ & - & & & & & & & & & & & & & & & \\
\hline Eikenella corrodens & $89 \cdot 6$ & $88 \cdot 5$ & $89 \cdot 5$ & $85 \cdot 5$ & $91 \cdot 6$ & - & & & & & & & & & & & & & & \\
\hline Kingella denitrificans & $88 \cdot 7$ & $88 \cdot 0$ & $89 \cdot 2$ & $84 \cdot 5$ & $91 \cdot 5$ & $97 \cdot 3$ & - & & & & & & & & & & & & & \\
\hline Kingella kingae & $88 \cdot 6$ & $88 \cdot 0$ & $88 \cdot 7$ & $85 \cdot 1$ & $90 \cdot 8$ & $95 \cdot 4$ & $95 \cdot 7$ & - & & & & & & & & & & & & \\
\hline 9. Legionella pneumopbila & $82 \cdot 5$ & $82 \cdot 8$ & $81 \cdot 1$ & $80 \cdot 5$ & $82 \cdot 9$ & $82 \cdot 3$ & $83 \cdot()$ & 81.9 & - & & & & & & & & & & & \\
\hline 10. 'Leptotbrix discophora' & $90 \cdot 8$ & $90 \cdot 1$ & $89 \cdot 2$ & $91 \cdot 4$ & $88 \cdot 4$ & $87 \cdot 5$ & $86 \cdot ?$ & $86 \cdot 9$ & $81 \cdot 3$ & - & & & & & & & & & & \\
\hline 11. Neisseria elongata & $88 \cdot 4$ & $87 \cdot 9$ & $88 \cdot 6$ & $85 \cdot 6$ & $91 \cdot 5$ & $97 \cdot 0$ & $97 \cdot 1$ & $95 \cdot 5$ & $82 \cdot 8$ & $86 \cdot 7$ & - & & & & & & & & & \\
\hline Neisseria gonorrboeae & $89 \cdot 1$ & 87.6 & $87 \cdot 8$ & $84 \cdot 8$ & $90 \cdot 5$ & $95 \cdot 0$ & $95 \cdot 2$ & $94 \cdot 4$ & $82 \cdot 0$ & $86 \cdot 5$ & $95 \cdot 8$ & - & & & & & & & & \\
\hline Nitrosolobus multiformis & $89 \cdot 4$ & $90 \cdot 0$ & $89 \cdot 1$ & $88 \cdot 1$ & 88.9 & $87 \cdot 6$ & $87 \cdot 3$ & $87 \cdot 1$ & $83 \cdot 5$ & $87 \cdot 8$ & $87 \cdot 6$ & $87 \cdot 1$ & - & & & & & & & \\
\hline Oceanospirillum linum & $83 \cdot 6$ & $82 \cdot 6$ & $82 \cdot 6$ & $81 \cdot 1$ & $83 \cdot 9$ & $82 \cdot 5$ & $83 \cdot 5$ & $82 \cdot 6$ & $87 \cdot 5$ & $81 \cdot 5$ & $83 \cdot 1$ & $82 \cdot 6$ & $82 \cdot 3$ & - & & & & & & \\
\hline Burkholderia cepacia & $92 \cdot 3$ & $92 \cdot 1$ & $89 \cdot 9$ & $89 \cdot 1$ & $89 \cdot 6$ & $89 \cdot 0$ & $88 \cdot 4$ & $89 \cdot 0$ & $83 \cdot 0$ & $90 \cdot 0$ & $89 \cdot 0$ & $88 \cdot 6$ & $88 \cdot 9$ & $83 \cdot 3$ & - & & & & & \\
\hline 16. Rubrivivax gelatinosus & $91 \cdot 3$ & $90 \cdot 3$ & 88.6 & $91 \cdot 7$ & $89 \cdot 2$ & $87 \cdot 6$ & $86 \cdot 6$ & $86 \cdot 3$ & $82 \cdot 2$ & $96 \cdot 7$ & $86 \cdot 7$ & $86 \cdot 3$ & $88 \cdot 2$ & $82 \cdot 9$ & $91 \cdot 0$ & - & & & & \\
\hline Rhodocyclus purpureus & $89 \cdot 8$ & $89 \cdot 6$ & $89 \cdot 3$ & 87.9 & $89 \cdot 5$ & $88 \cdot 0$ & $88 \cdot 0$ & $88 \cdot 0$ & $83 \cdot 9$ & $89 \cdot 7$ & $88 \cdot 8$ & $88 \cdot 2$ & $90 \cdot 2$ & $82 \cdot 9$ & $90 \cdot 8$ & $89 \cdot 5$ & - & & & \\
\hline 18. Sphaerotilus natans & $90 \cdot 1$ & $89 \cdot 6$ & 88.9 & $91 \cdot 2$ & $87 \cdot 3$ & $87 \cdot 0$ & $86 \cdot 3$ & $86 \cdot 3$ & $80 \cdot 5$ & $96 \cdot 5$ & $86 \cdot 5$ & $85 \cdot 9$ & $87 \cdot 8$ & $81 \cdot 0$ & $90 \cdot 0$ & $95 \cdot 2$ & 88.8 & - & & \\
\hline Spirillum volutans & $88 \cdot 0$ & 88.4 & $88 \cdot 2$ & 85.9 & $87 \cdot 3$ & $88 \cdot 1$ & $88 \cdot 3$ & $88 \cdot 4$ & $83 \cdot 6$ & $87 \cdot 7$ & $87 \cdot 8$ & $87 \cdot 0$ & 88.6 & $84 \cdot 3$ & $89 \cdot 6$ & $87 \cdot 7$ & $89 \cdot 6$ & $87 \cdot 3$ & - & \\
\hline Telluria mixta & $90 \cdot 4$ & $90 \cdot 5$ & $89 \cdot 3$ & $88 \cdot 3$ & $89 \cdot 4$ & $88 \cdot 3$ & $87 \cdot 6$ & $87 \cdot 0$ & $82 \cdot 1$ & $88 \cdot 7$ & $88 \cdot 0$ & $87 \cdot 0$ & $90 \cdot 4$ & $81 \cdot 9$ & $89 \cdot 8$ & $89 \cdot 0$ & $89 \cdot 1$ & $87 \cdot 9$ & $87 \cdot 7$ & - \\
\hline Thauera selenatis & $89 \cdot 0$ & $88 \cdot 7$ & 87.5 & $85 \cdot 9$ & $88 \cdot 5$ & $88 \cdot 4$ & $87 \cdot 7$ & $86 \cdot 7$ & $82 \cdot 2$ & $88 \cdot 4$ & $87 \cdot 9$ & $87 \cdot 4$ & $87 \cdot 4$ & $82 \cdot 5$ & $88 \cdot 2$ & $88 \cdot 3$ & $90 \cdot 8$ & $88 \cdot 4$ & $87 \cdot 0$ & $87 \cdot 5$ \\
\hline
\end{tabular}

shows that strain AB2188 forms an independent line of descent that is almost equidistant to those leading to representatives of other taxa. Strain AB2188 is neither a member of the genus Burkholderia (Yabuuchi et al., 1992) nor of the phylogenetically defined species cluster that embraces the genera Eikenella, Neisseria, Kingella (Dewhirst et al., 1989), Simonsiella, Alysiella and Moraxella (Rossau et al., 1989; Morse \& Knapp, 1991), whose members are also described to contain human and animal pathogens and saprophytes from the oral cavity.

\section{DISCUSSION}

We have rediscovered a micro-organism from the human oral flora and described its phenotypic and genotypic profile. The characteristic small motile coccoid form seen in wet mounts of scrapings from the gingival margin or back of the tongue of apparently healthy people may be the motile form of the organism described here, but we cannot be sure; however, observation of such motile bacteria initiated this study. 


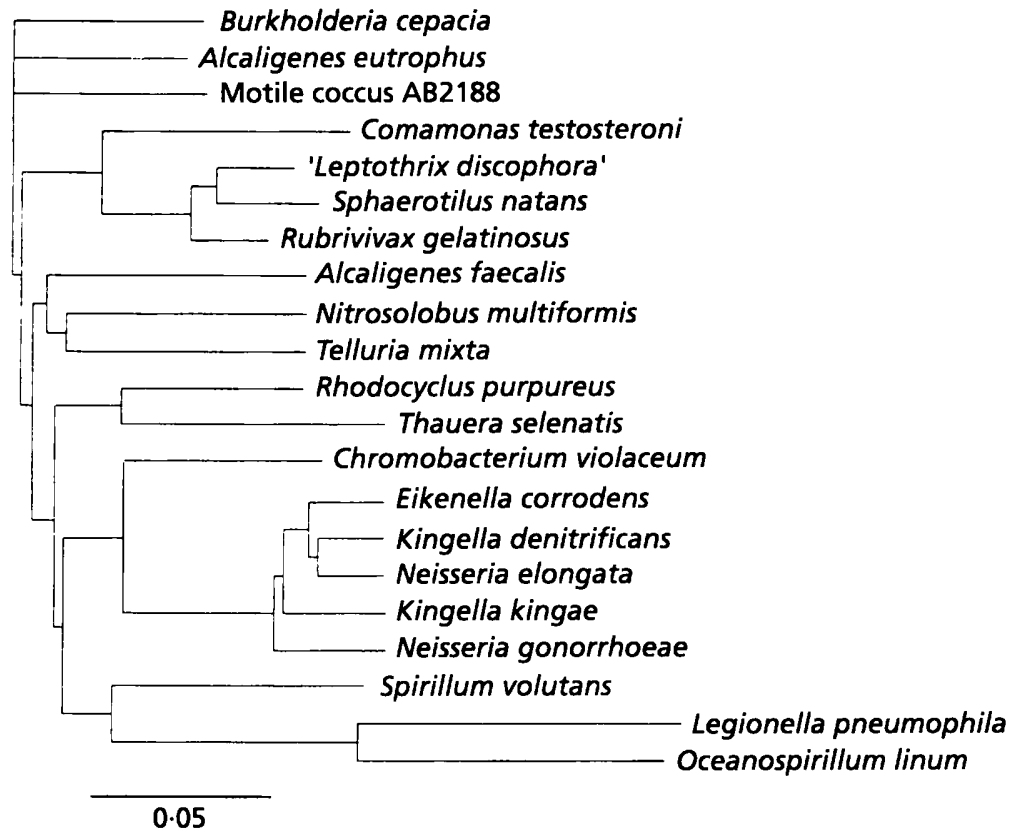

Fig. 7. Phylogenetic position of strain
AB2188 within the radiation of
representatives of the beta-subclass of
Proteobacteria, based on the least squares
algorithm. The scale bar represents $10 \%$
sequence divergence. The total distance
between two organisms is the sum of the
horizontal branch lengths. Reference 165
rRNADNA sequences have been published
in the Ribosome Database Project (Olsen et
al., 1992) or are available from the authors.

The ultrastructure showed a pleomorphic picture of a micro-organism with a Gram-negative cell-wall profile and a series of different stages from single coccoid forms with flagella to aggregates of irregular cells held together by a common surface layer. The biochemical profiles of the strains were very uniform, suggesting that they belong to one species. The strains did not produce dextran or levan as shown by the ethanol precipitation method; however, polysaccharide was apparently produced by all strains on sucrose agar plates. These findings are not necessarily contradictory; the polysaccharide produced on the plated medium may be different from dextran and levan, or the aerobic conditions on the plates may have favoured the production of levan or dextran. No attempt was made to characterize this polysaccharide chemically. No growth was observed on enteric media, azide agar, EYA and bile-agar plates using a standard inoculum of the strains. Growth was supported on these media only when a large inoculum was used. However, this phenomenon may be due to transferral of nutrients from the chocolate agar plates from which the inoculum was taken.

There is no indication of a pathogenic potential for the organism. We did not study dental plaque or try to isolate the organism from dental plaque. However, the structure and features of this organism (polysaccharide formation) are compatible with its participation in the formation of dental plaque.

The rRNA sequencing data showed that the organism belongs to a separate branch of the beta-subclass of Proteobacteria most closely related to the genus Burkbolderia. The isolated position together with the unique combination of chemotaxonomic and phenotypic properties indicate that the group of motile cocci represent a new genus and species. We propose the name Lautropia mirabilis for this organism.

\section{Description of Lautropia mirabilis gen. nov. sp. nov.}

Lautropia mirabilis [Lau.tro'pia, in honour of the late Hans Lautrop, Danish bacteriologist, who pointed to the possible identity of our isolates with Ørskov's 'Sarcina mirabilis'; mi.ra'bi.lis. The specific epithet was kept from Ørskov's original description (1930)].

Gram-negative cocci occurring in at least three forms: (1) encapsulated cocci, $1-2 \mu \mathrm{m}$ in diameter, often occurring in clusters of $10->100$ cells; (2) unencapsulated cocci, 1-2 $\mu \mathrm{m}$ in diameter, motile by the action of a tuft of three to nine flagella; and (3) large, $>5 \mu \mathrm{m}$ in diameter, sphaeroblast-like cells. Facultative, but grows best under aerobic conditions with no requirement for $\mathrm{CO}_{2}$. Mesophilic, growing at temperatures between $30^{\circ} \mathrm{C}$ and $44^{\circ} \mathrm{C}$. Non-pigmented, grows on most enriched media, especially on chocolate, Levinthal, TGY and Tween 80 agar; grows slower with no haemolysis on horse-blood agar. At least three colony morphologies are seen: (1) flat, dry, circular colonies predominating in young cultures, becoming (2) larger, wrinkled, crisp and crateriform on prolonged incubation, and (3) smooth, glistering, raised, round, mucoid colonies. The colony diameter varies between pinpoint size and more than $5 \mathrm{~mm}$; all colony types may occur in all sizes, largest in older cultures; colonies are usually adherent to the substrate. Growth in broth is granular with a coarse sediment and granules adherent to the side of the tube. Biochemically, strains are oxidase, catalase and urease positive, reduce nitrate and nitrites, produce polysaccharide on sucrose agar, ferment glucose, fructose, maltose, sucrose and mannitol and do not ferment lactose, trehalose, raffinose, inulin, salicin, adonitol, dulcitol, sorbitol, inositol, xylose, rhamnose or arabinose or hydrolyse starch. Most strains hydrolyse esculin. They may produce $\beta$-xylosidase, but not $\beta$ galactosidase or $\beta$-glucuronidase. Do not decarboxylate 
lysine or ornithine and do not produce arginine decarboxylase/dihydrolase or phenylalanine deaminase. VP, gelatinase, $\mathrm{H}_{2} \mathrm{~S}$ negative; do not hydrolyse hippurate or Tween 80 . Sensitive to penicillin $G$, ampicillin, piperacillin, cefuroxime, gentamicin and erythromycin. Mean $\mathrm{mol} \%(\mathrm{G}+\mathrm{C})$ is 65 (range 64.6-65.4). The habitat is the human oral cavity.

The type strain is AB2188 (= NCTC 12852).

\section{Description of the type strain}

Strain AB 2188 has all the above mentioned characteristics except for not hydrolysing esculin and not producing $\beta$ xylosidase. It was isolated from human dental plaque.

\section{REFERENCES}

Bergquist, L. M. \& Searcy, R. L. (1963). A micro method for detection of utilization of phenylalanine by microorganisms. $\mathrm{Am} \mathrm{J}$ Clin Pathol 39, 544-545.

Blom, J., Hansen, G. H. \& Poulsen, F. M. (1983). Morphology of cells and hemagglutinogens of Bordetella species: resolution of substructural units in fimbriae of Bordetella pertussis. Infect Immun 42, 308-317.

Brosius, J., Palmer, J. L., Kennedy, J. P. \& Noller, H. F. (1978). Complete nucleotide sequence of a $16 \mathrm{~S}$ ribosomal RNA gene from Eschericbia coli. Proc Natl Acad Sci US A 75, 4801-4805.

Bülow, P. (1964). The ONPG test in diagnostic bacteriology. Acta Pathol Microbiol Scand 60, 376-386.

Carlsson, J. (1968). A numerical taxonomic study of human oral streptococci. Odontol Revy 19, 137-160.

De Soete, G. (1983). A least squares algorithm for fitting additive trees to proximity data. Psychometrika 48, 621-626.

Dewhirst, F. E., Paster, B. J. \& Bright, P. C. (1989). Chromobacterium, Eikenella, Kingella, Neisseria, Simonsiella and Vitreoscilla species comprise a major branch by $16 \mathrm{~S}$ ribosomal ribonucleic acid sequence comparison: transfer of Eikenella and Simonsiella to the family Neisseriaceae (emend.). Int J Syst Bacteriol 39, 258-266.

Dorsch, M. \& Stackebrandt, E. (1992). Some modifications in the procedure of direct sequencing of PCR amplified 16S rDNA. $J$ Microbiol Methods 16, 271-279.

Gerner-Smidt, P. (1989). Frequency of plasmids in Acinetobacter calcoaceticus. J Hosp Infect 14, 23-28.

Gibbons, R. J. \& Banghart, S. B. (1967). Synthesis of extracellular dextran by carcinogenic bacteria and its presence in human dental plaque. Arcb Oral Biol 12, 11-24.

Hendrichson, D. A. \& Krenz, M. M. (1991). Reagents and stains. In Manual of Clinical Microbiology, 5th edn, chapter 122, p. 1313. Edited by A. Balows, W. J. Hausler, Jr, K. L. Herrmann, H. D. Isenberg \& H. J. Shadomy. Washington, DC: American Society for Microbiology.

Holmes, D. S. \& Quigley, M. (1981). A rapid method for the preparation of bacterial plasmids. Anal Biochem 114, 193-197.

Hugh, R. \& Leifson, E. (1953). The taxonomic significance of fermentative versus oxidative metabolism of carbohydrates by various Gram negative bacteria. J Bacteriol 66, 24-26.

Jukes, T. H. \& Cantor, C. R. (1969). Evolution of protein molecules. In Mammalian Protein Metabolism, vol. 3, pp. 21-132. Edited by H. N. Munro. New York: Academic Press.

Kilian, M. \& Bülow, P. (1976). Rapid diagnosis of Enterobacteriaceae. I. Detection of bacterial glycosidases. Acta Pathol Microbiol Scand Sect B 84, 245-251.
Klesius, P. H., Lippincott, S. C. \& Bienvenu, R. J. (1962). Unusual Gram-negative organism from the oral flora.J Bacteriol 84, 378-380.

Koch, R. (1884). Konferenz zur Erörterung der Cholerafrage am 26 Juli 1884 in Berlin. Berliner Klinischer Wochenschrift no. 31, 32 and 32a. (Reprinted in Gesammelte Werke von Robert Koch, Band II, 1. Teil, p. 20-60. Leipzig: Verlag von Georg Thieme, 1912).

Kolmos, H. J. \& Schmidt, J. (1987). Failure to detect hydrogensulphide production in lactose/sucrose fermenting Enterobacteriaceae, using triple sugar iron agar. Acta Patbol Microbiol Immunol Scand Sect B 95, 85-87.

Kovács, N. (1956). Identification of Pseudomonas pyocyanea by the oxidase reaction. Nature 176, 703.

Lautrop, H. (1960). Laboratory diagnosis of whooping cough or Bordetella infections. Bull WHO 23, 15-35.

Li, X., Dorsch, M., Del Dot, T., Sly, L. I., Stackebrandt, E. \& Hayward, A. C. (1993). Phylogenetic studies of the rRNA group II pseudomonads based on $16 \mathrm{~S}$ rRNA gene sequences. $J A p p l$ Microbiol 74, 324-329.

Lind, E. \& Ursing, J. (1986). Clinical strains of Enterobacter agglomerans (synonyms: Erwinia berbicola, Erwinia milletiae) identified by DNA-DNA hybridization. Acta Patbol Microbiol Immunol Scand Sect B 94, 205-213.

Melchior, N. H., Blom, J., Tybring, L. \& Birch-Andersen, A. (1973). Light and electron microscopy of the early response of Escherichia coli to a 6- $\beta$-amidinopenicillanic acid (FL 1060). Acta Patbol Microbiol Immunol Scand Sect B 81, 393-407.

Møller, V. (1955). Simplified tests for some amino acid decarboxylases and for the arginine dihydrolase system. Acta Pathol Microbiol Scand 36, 158-172.

Morse, S. A. \& Knapp, J. S. (1991). The genus Neisseria. In The Prokaryotes, pp. 2495-2529. Edited by A. Balows, H. G. Trüper, M. Dworkin, W. Harder and K. H. Schleifer. Berlin: Springer Verlag.

Neubauer, T. \& Berger, U. (1961). Polysaccharidbildung aus saccharose durch einen 'saccharosenegativen' keim: Neisseria flavescens. Naturwissenschaften 48, 405-406.

Olsen, G. J., Overbeek, R., Larsen, N., Marsh, T. L., McCaughey, M. J., Maciukenas, M. A., Kuan, W. M., Macke, T. J. \& Woese, C. R. (1992). 'The ribosomal database project. Nucleic Acids Res 20S, 2199-2200.

O'Meara, R. A. Q. (1931). A simple, delicate and rapid method of detecting the formation of acetylmethylcarbinol by bacteria fermenting carbohydrate. J Patbol Bacteriol 34, 401-406.

Ørskov, J. (1930). Untersuchungen über einen in Mundhöhle und oberen Luftwegen häufig vorkommenden, zur Sarcinagruppe gehörigen Mikroben, der eigentümliche morphologische Verhältnisse aufweist. Acta Pathol Microbiol Scand Suppl III, 519-541.

Rainey, F. A. \& Stackebrandt, E. (1993). Phylogenetic analysis of the bacterial genus Thermobacteroides indicates an ancient origin of Thermobacteroides proteolyticus. Lett Appl Microbiol 16, 282-286.

Rainey, F. A., Dorsch, M., Morgan, H. W. \& Stackebrandt, E. (1992). 16S rDNA analysis of Spirochaeta thermophila: its phylogenetic position and implications for the systematics of the order Spirochaetales. Syst Appl Microbiol 15, 197-202.

Rossau, R., Vandenbussche, F., Thielemans, S., Segers, P., Grosch, H., Göthe, E., Mannheim, W. \& De Ley, J. (1989). Ribosomal ribonucleic acid cistron homologies of Neisseria, Kingella, Simonsiella, Alysiella and Centers for Disease Control Group EF-4 and M5 in the emended family Neisseriaceae. Int J Syst Bacteriol 39, 185-189.

Sandstedt, K., Ursing, J. \& Walder, M. (1983). Thermotolerant Campylobacter with no or weak catalase activity isolated from dogs. Curr Microbiol 8, 209-213. 
Schiött, C. R. (1967). An unidentified Gram negative rod isolated from the gingiva. J Periodontal Res 2, 242-243.

Stackebrandt, E. \& Charfreitag, O. (1990). Partial 16S rRNA pr:mary structure of five Actinomyces species: phylogenetic implications and development of an Actinomyces israelii specific oligonucleotide probe. J Gen Microbiol 136, 37-43.

Vaughn, R. H. \& Levine, M. (1942). Differentiation of the 'intermediate' coli-like bacteria. J Bacteriol 44, 487-505.
Yabuuchi, E., Kosako, Y., Oyaizo, H., Yano, I., Hotta, H., Hashimoto, Y., Ezaki, T. \& Arakawa, M. (1992). Proposal of Burkbolderia gen. nov. and transfer of seven species of the genus Pseudomonas homology group II to the new genus, with the type species Burkbolderia cepacia (Palleroni \& Holmes, 1981) comb. nov. Microbiol Immunol 36, 1251-1275.

Received 4 November 1993; accepted 13 January 1994. 